\title{
A Rare Presentation of Basal Cell Carcinoma Arising within Trichoepithelioma: A Diagnostic Challenge
}

Tanya Greywal ${ }^{1}$, Ashley G. Rubin ${ }^{2}$, Brian Jiang ${ }^{1}$

1. Dermatology, University of California San Diego, La Jolla, USA 2. Mohs Surgery, Bernardo Dermatology Medical Group, Poway, USA

Corresponding author: Tanya Greywal, tgreywal@gmail.com

\begin{abstract}
Differentiating between trichoepithelioma and basal cell carcinoma (BCC) is sometimes diagnostically challenging. We present a case of a 61-year-old male with a BCC arising within a trichoepithelioma, which is rarely reported in the literature. Clinical and histological diagnosis of trichoepithelioma is sometimes complicated by its many similarities to BCC. Therefore, immunohistochemical analysis and adequate tissue sampling are essential in suspicious lesions. In addition, as represented by our patient's presentation, it is important for clinicians to remember that the presence of a concurrent malignant neoplasm may be masked by the benign nature of a trichoepithelioma and that a superficial shave biopsy may not be sufficient for accurately diagnosing such suspicious lesions.
\end{abstract}

Categories: Dermatology, Pathology

Keywords: basal cell carcinoma, immunohistochemistry, diagnosis, treatment, trichoepithelioma

\section{Introduction}

Trichoepithelioma is a benign hair follicle tumor with many of its clinical and histologic features similar to those of basal cell carcinoma (BCC). Thus, differentiating between these two entities is sometimes diagnostically challenging. We present a case of a 61 -year-old male with a BCC arising within a trichoepithelioma, which is rarely reported in the literature (Poster and Abstract: Greywal T, Rubin A, Jiang SB. Basal Cell Carcinoma Arising within Trichoepithelioma: A Rare Presentation and Diagnostic Challenge. American Academy of Dermatology 76th Annual Meeting; Feb 16-20, 2018).

\section{Case Presentation}

A 61-year-old man with no previous history of any type of skin cancer presented with a "spot" on his neck that had been present for 30 years. The lesion slowly increased in size and was associated with intermittent swelling. Cutaneous examination of the neck revealed a $1.5 \mathrm{~cm}$ by $2.3-\mathrm{cm}$ multilobular plaque with overlying

Received 07/19/2019

Review began 08/05/2019

Review ended 08/06/2019

Published 08/16/2019

(c) Copyright 2019

Greywal et al. This is an open access article distributed under the terms of the Creative Commons Attribution License CC-BY 3.0., which permits unrestricted use, distribution, and reproduction in any medium, provided the original author and source are credited. telangiectasias (Figure 1).

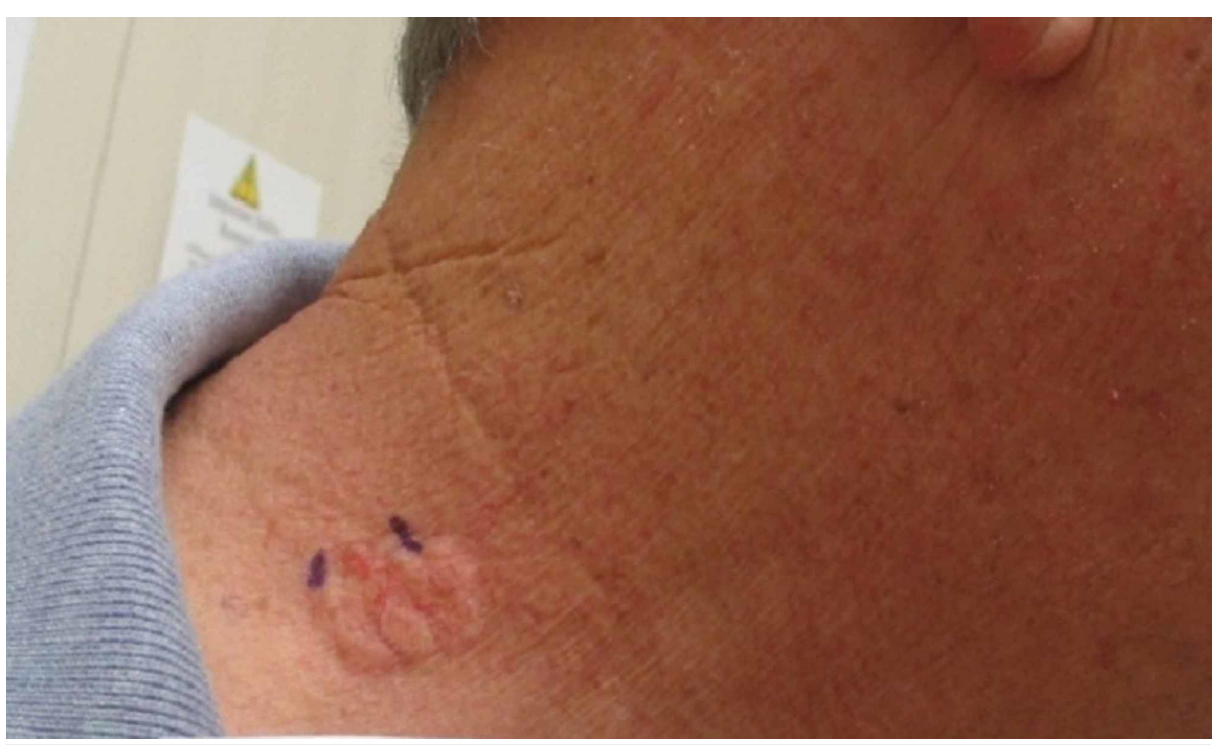

FIGURE 1: Clinical presentation

A $1.5 \mathrm{~cm}$ by $2.3-\mathrm{cm}$ yellow, multilobular plaque with overlying telangiectasias on the patient's neck (purple 


\section{Cureus}

ink markings define, in part, the margins of the lesion)

A skin biopsy of the lesion was performed (Figures 2-5).

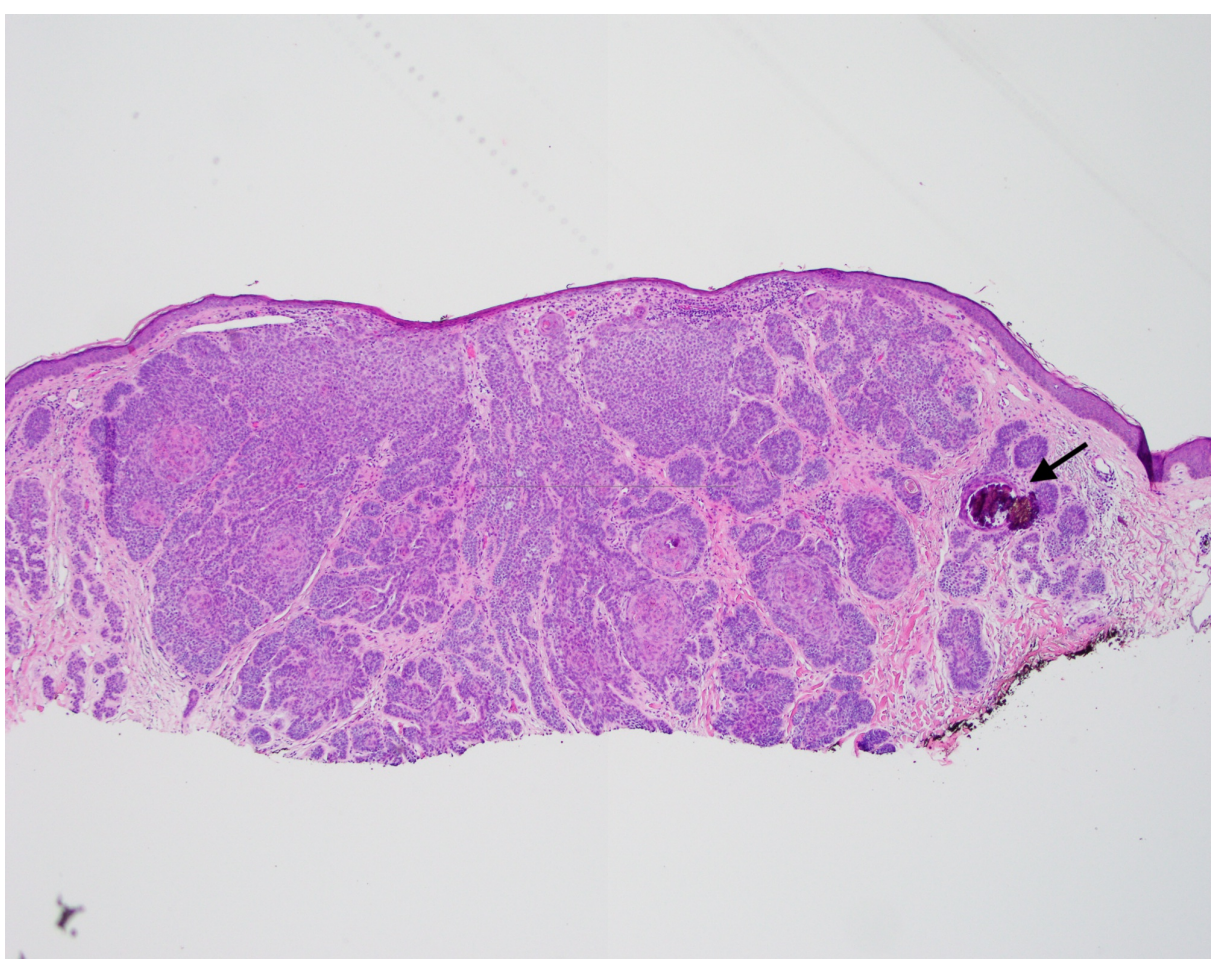

FIGURE 2: Lower power view of skin biopsy

Low power view (4x) showing a multi-lobular basaloid neoplasm with focal dystrophic calcification (arrow).

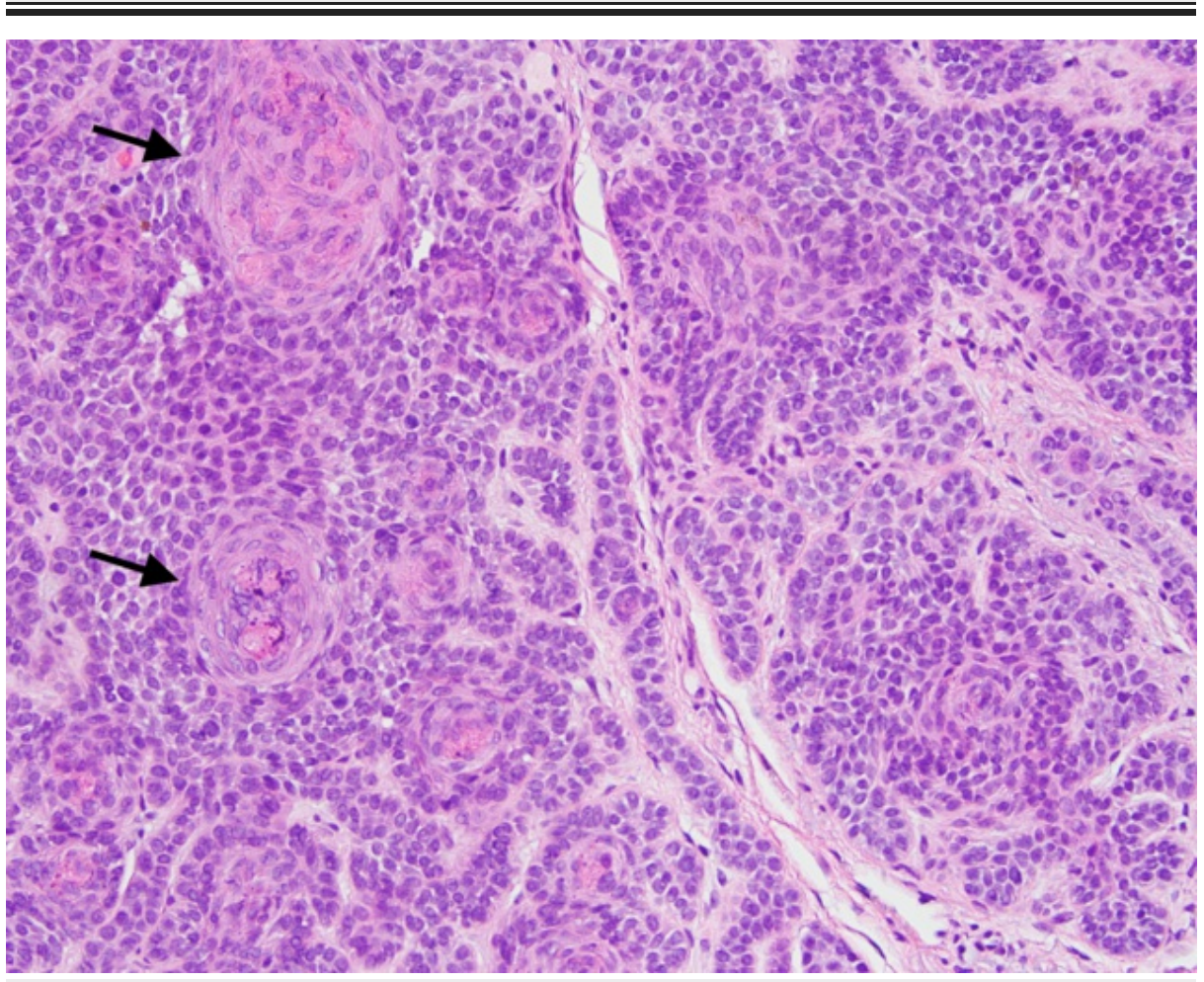

FIGURE 3: High power view of skin biopsy

High power view (20x) showing primitive follicular differentiation (arrows) 


\section{Cureus}

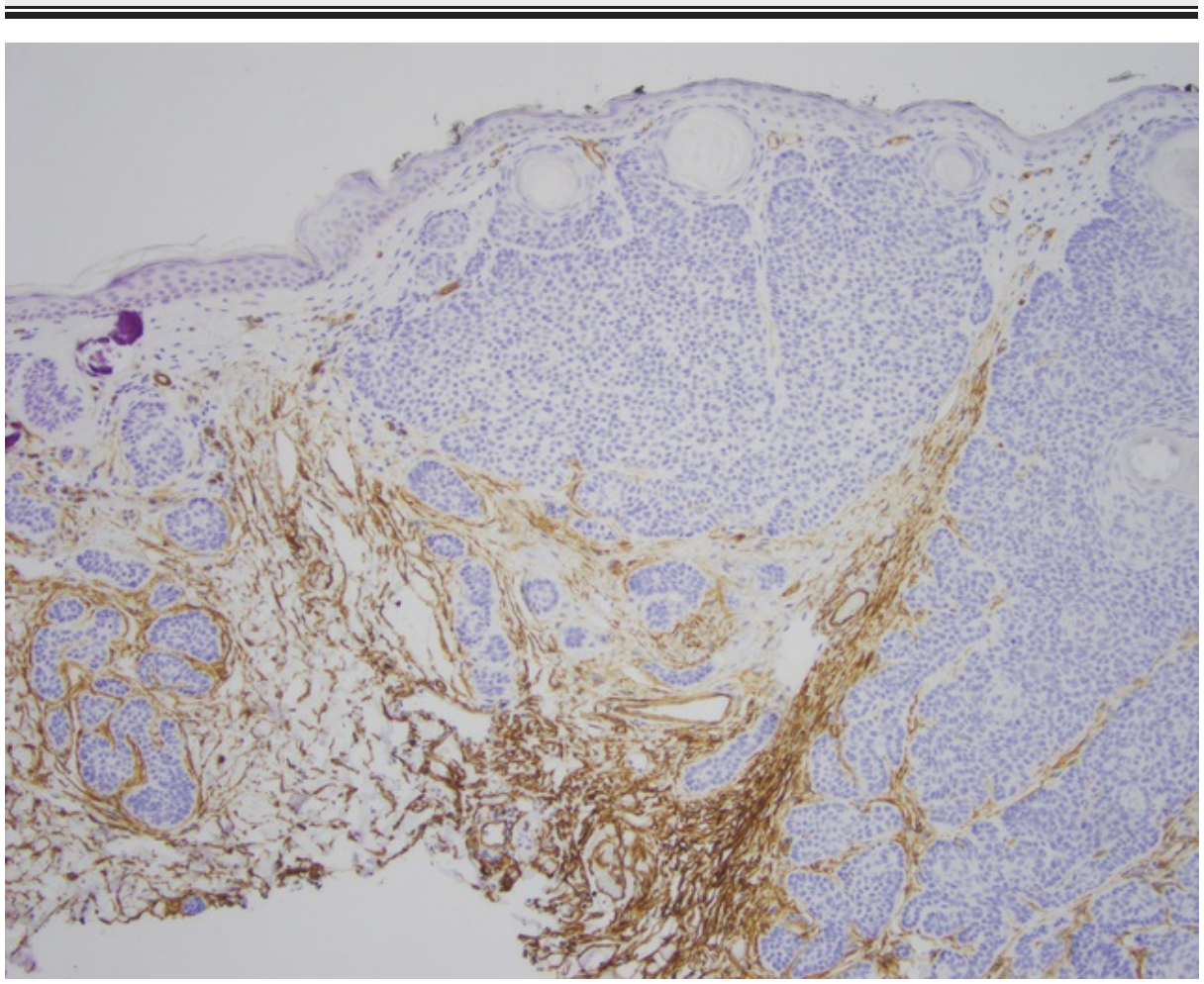

\section{FIGURE 4: CD34 immunohistochemistry of skin biopsy}

CD34 immunohistochemistry (brown stain) showing intimate CD34 positive fibroblastic component, which supports the diagnosis of trichoepithelioma

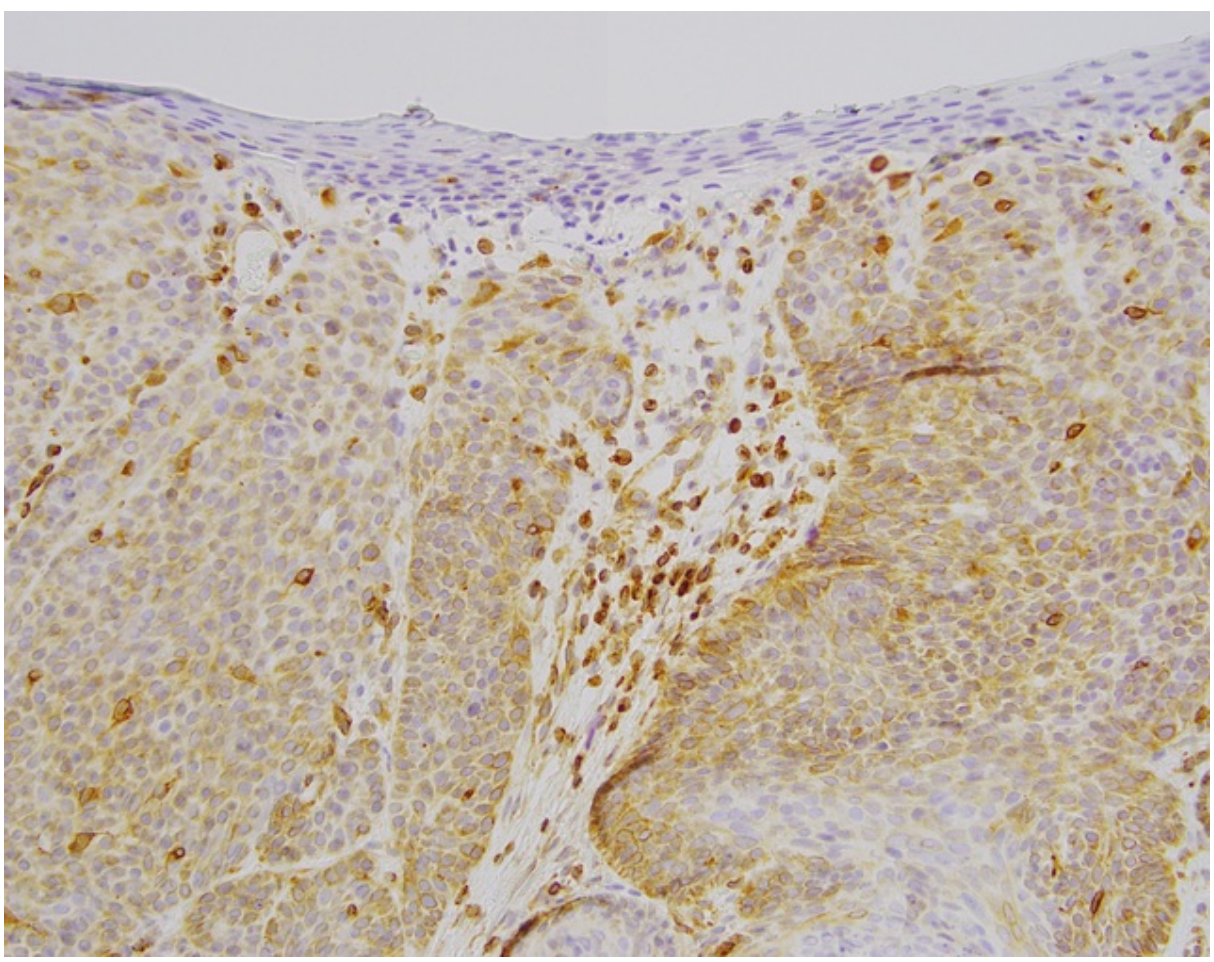

\section{FIGURE 5: Bcl-2 immunohistochemistry}

$\mathrm{Bcl}-2$ immunohistochemistry demonstrating decoration of individual tumor cells along the periphery (as seen in trichoepithelioma) and with some areas of more diffuse expression (as seen in BCC) 


\section{Cureus}

Histopathologic examination revealed basaloid islands within a cellular stroma, follicular differentiation with papillary mesenchymal bodies, minimal atypia and apoptotic bodies, and no retraction artifact. Immunohistochemical staining was positive for CD34 in stromal cells and Bcl-2 in the peripheral cells of the basaloid islands; CK20 was negative. These findings were most consistent with trichoepithelioma. However, due to the overlapping histologic features with BCCs, a conservative surgical excision was performed to completely remove the lesion.

Histopathologic examination of the excised tissue revealed multiple basaloid nodules (Figures 6-11).

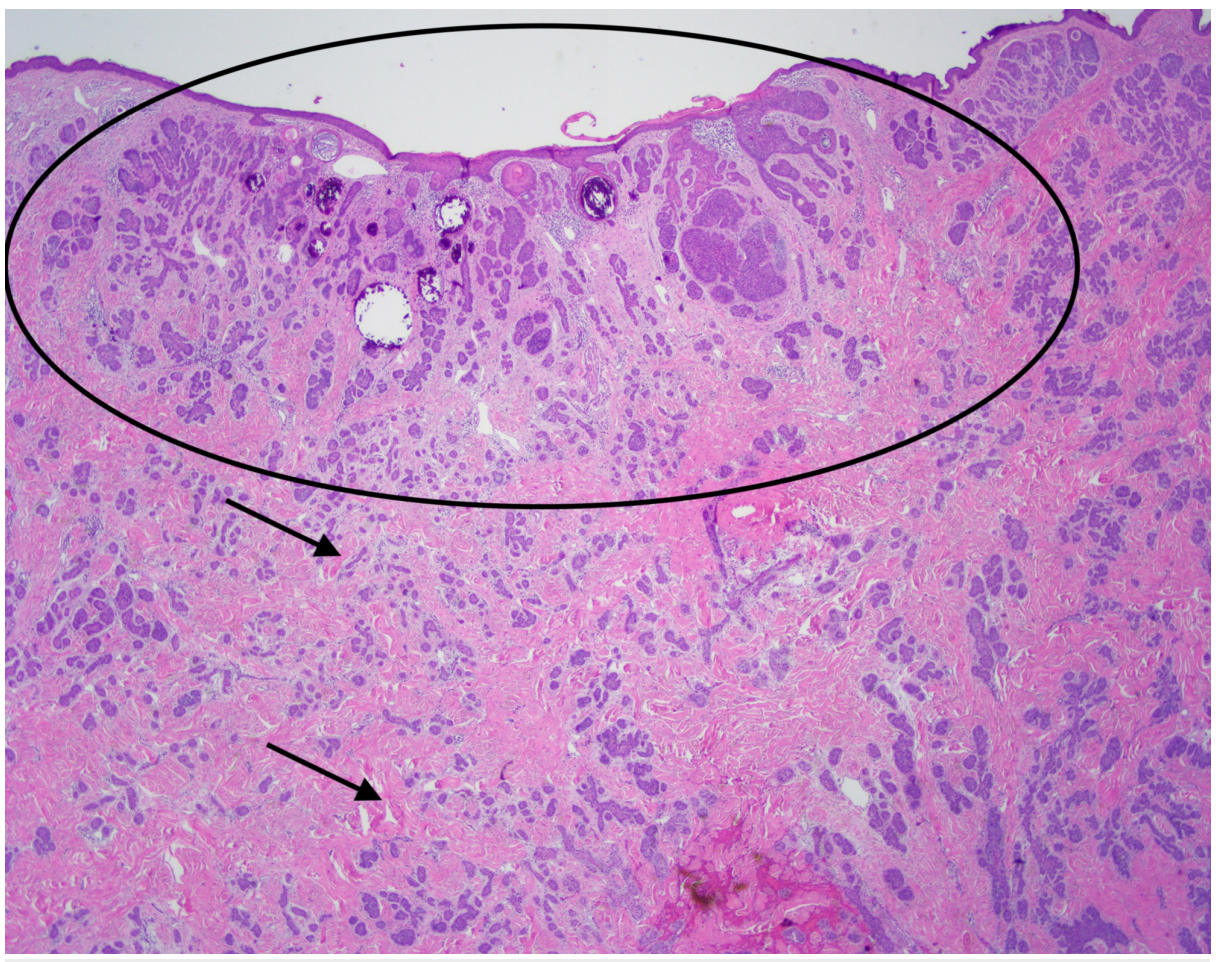

\section{FIGURE 6: Excisional biopsy}

Excisional biopsy showing superficial trichoepitheliod neoplasm (circle) with underlying diffusely infiltrative basal cell carcinoma (arrows) 


\section{Cureus}

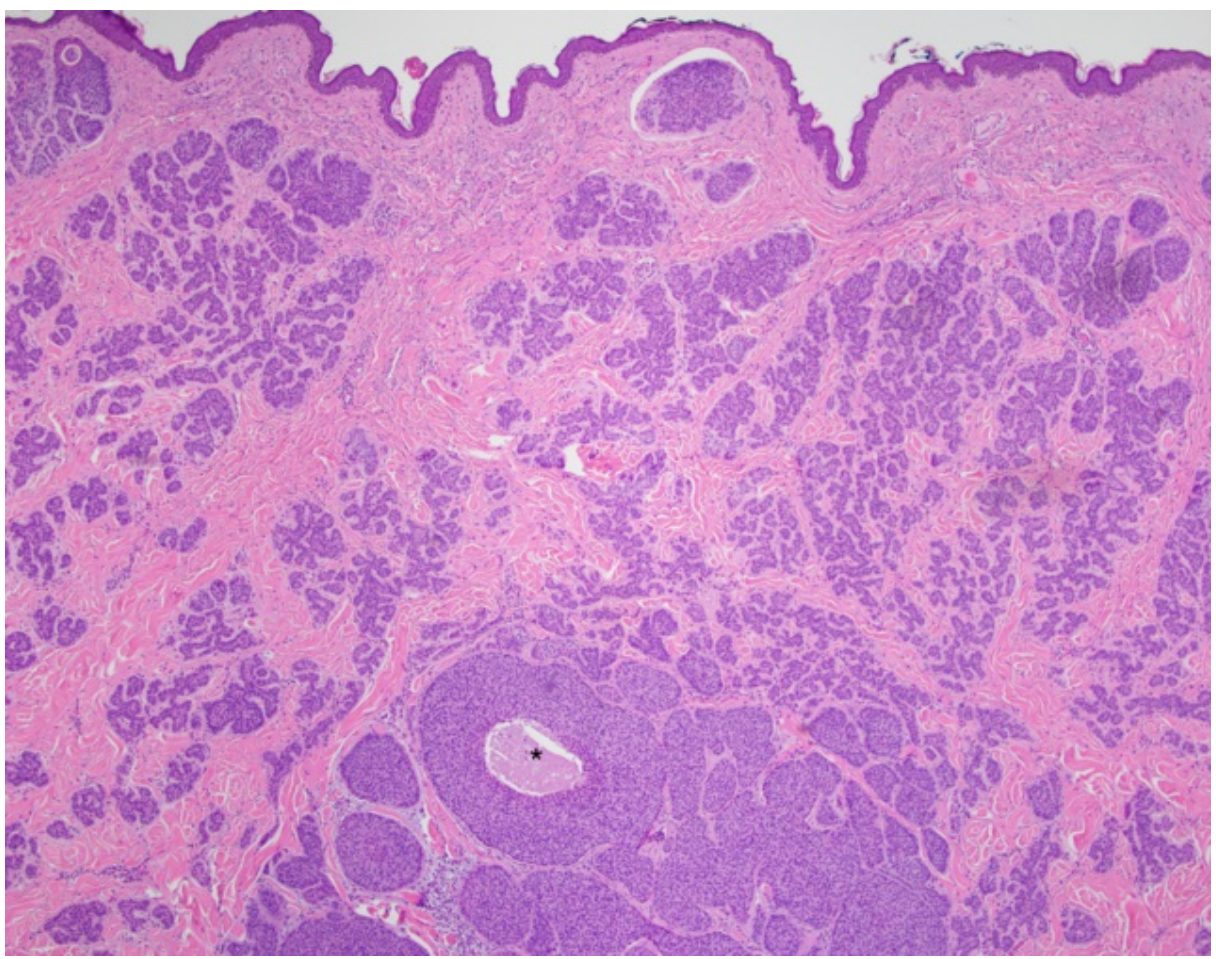

\section{FIGURE 7: Excisional biopsy, low power view}

Low power view $(4 \mathrm{x})$ of invasive basal cell carcinoma with focal cystic degeneration (asterisk)

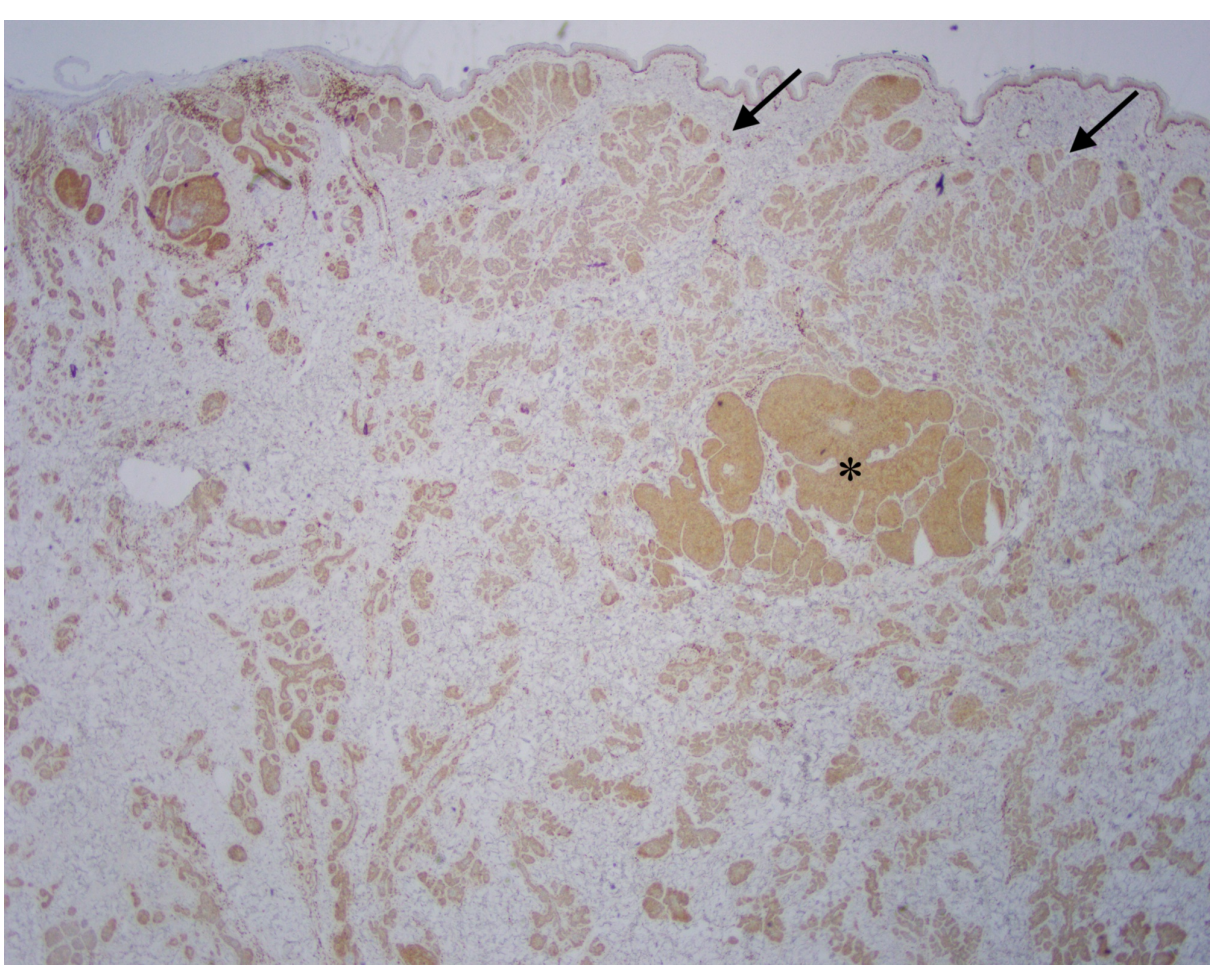

\section{FIGURE 8: Excisional biopsy, Bcl-2 immunohistochemistry}

$\mathrm{Bcl}-2$ staining with prominent expression in tumor cells. Note the staining pattern throughout the invasive BCC component (asterisk), and primarily along the periphery of the trichoepithelioma (arrows). 


\section{Cureus}



FIGURE 9: Excisional biopsy, low power view, Bcl-2 immunohistochemistry

Low power (4x) Bcl-2 stain with decoration of the majority of component basaloid cells consistent with BCC (arrows)

BCC, basal cell carcinoma

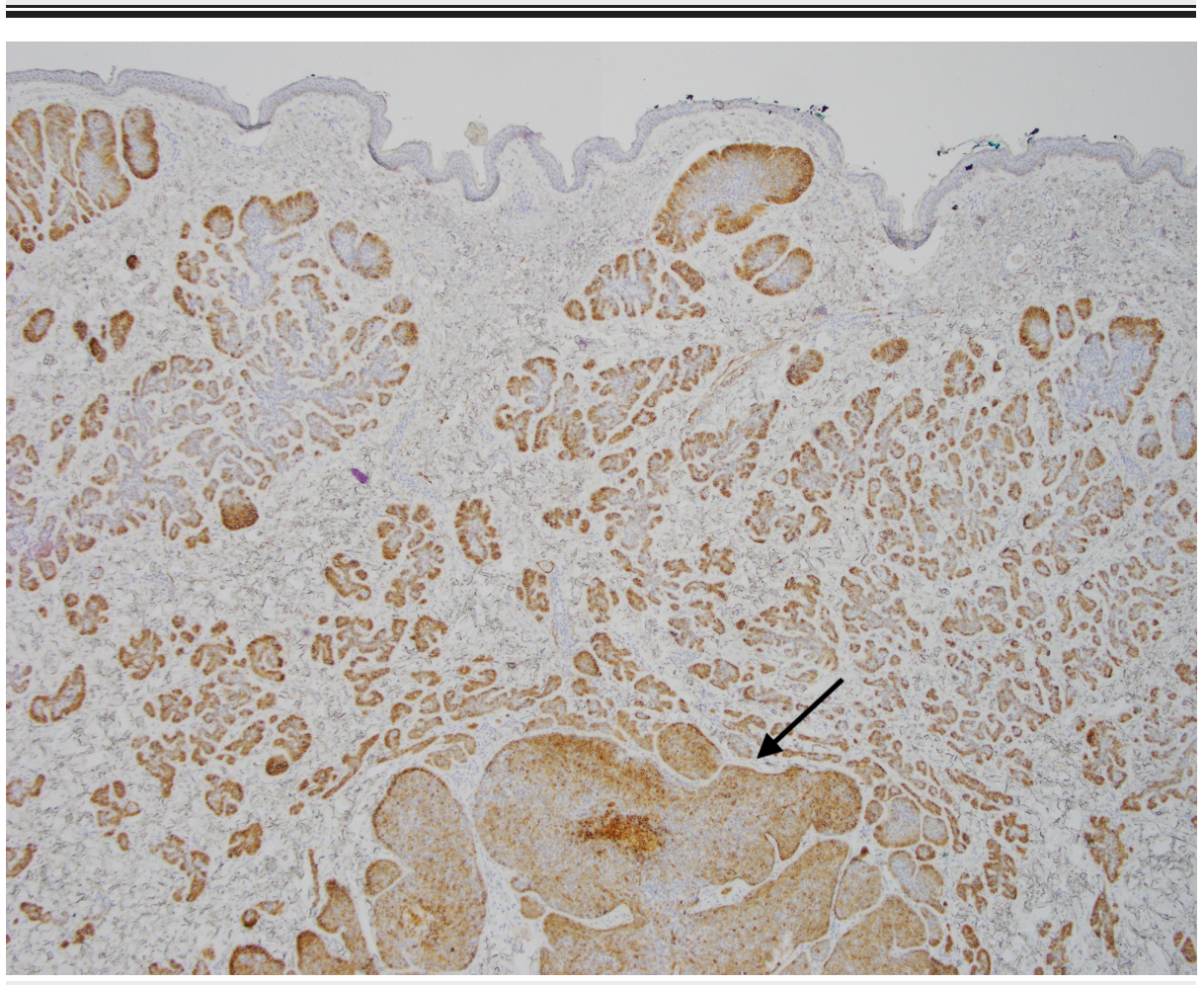

FIGURE 10: Excisional biopsy, CD10 immunohistochemistry

Low power view (4x) showing CD10 decoration of component BCC tumor cells (arrow)

BCC, basal cell carcinoma 


\section{Cureus}

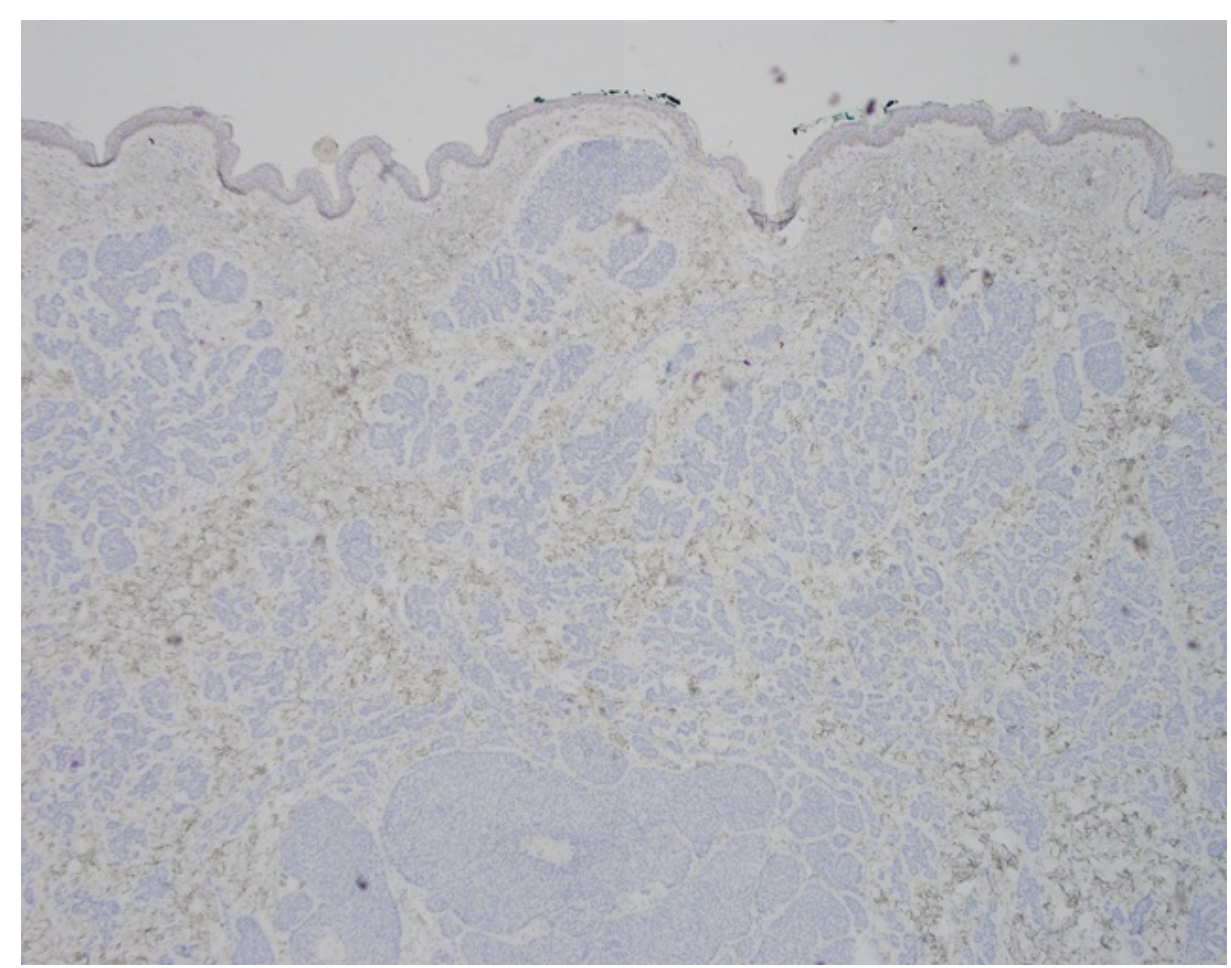

\section{FIGURE 11: Excisional biopsy, CK20 immunohistochemistry}

Negative CK20 stain with no significant expression within the more superficial trichoepithelioma or deeper BCC

BCC, basal cell carcinoma

Some of the larger nodules contained cystic formations, necrosis, peripheral retraction artifact, and increased atypia; the smaller nodules showed follicular differentiation. Immunohistochemical staining was diffusely positive for Bcl-2 and CD10 in these larger nodular and cystic areas, and peripherally positive in areas with follicular differentiation. CK20 remained negative in all components. Overall, these findings were most consistent with a multifocal, infundibulocystic basal cell carcinoma arising within a trichoepithelioma. Since the lesion extended broadly into the deep margins, re-excision was recommended.

The patient subsequently underwent a third and final procedure with Mohs micrographic surgery (MMS) to achieve optimal clearance of the margins. The final defect was $7.2 \mathrm{~cm}$ by $8.0 \mathrm{~cm}$ after four stages of MMS (Figure 12). 


\section{Cureus}

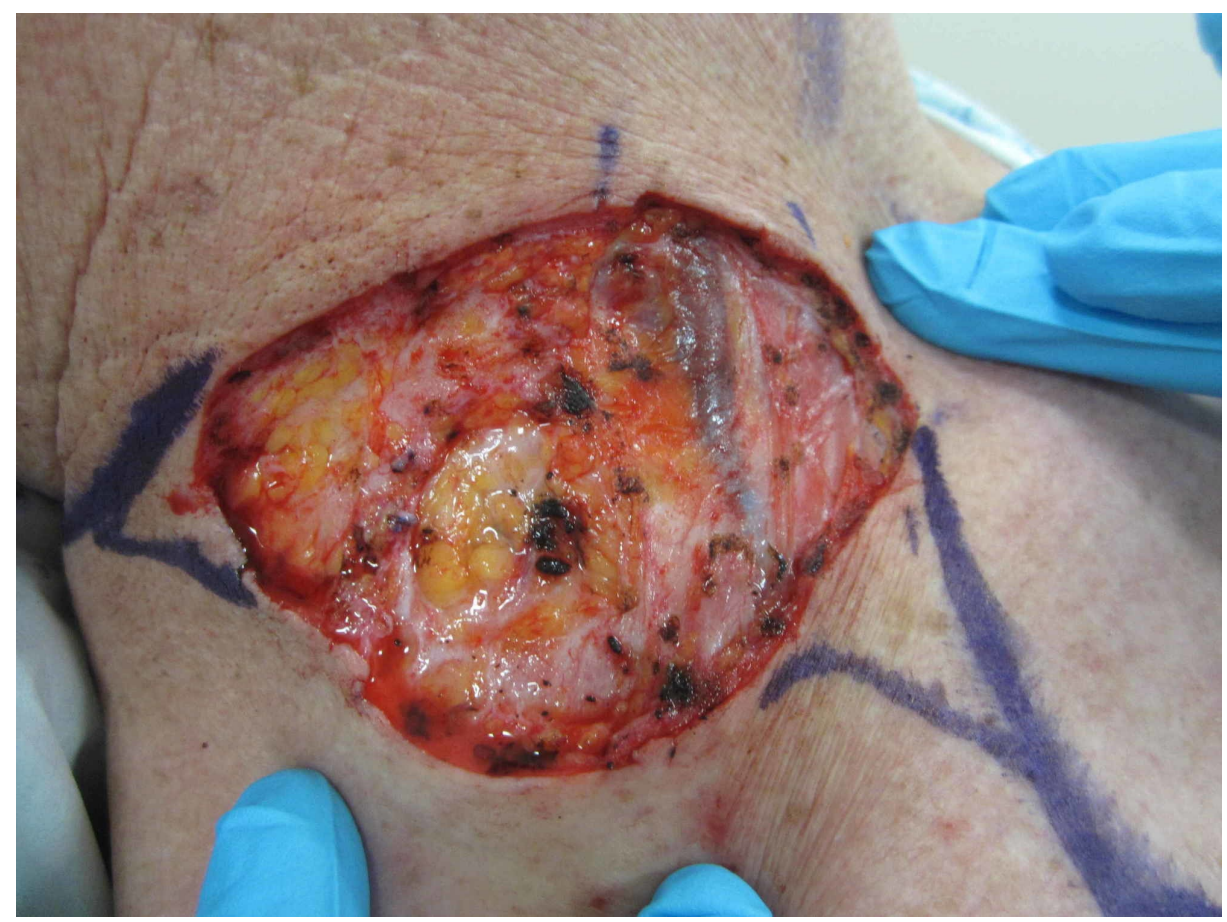

\section{FIGURE 12: Final Mohs surgery defect}

The final defect after four stages of Mohs micrographic surgery $(7.2 \mathrm{~cm}$ by $8.0 \mathrm{~cm})$

Following confirmation of negative margins, the resultant wound was repaired with an advancement flap.

\section{Discussion}

It is difficult to differentiate trichoepithelioma from BCC due to their many clinical and histologic similarities (Table 1 ).

\begin{tabular}{|c|c|c|}
\hline & Trichoepithelioma & Basal Cell Carcinoma \\
\hline Clinical Features & $\begin{array}{l}\text { - Typically presents as a skin-colored papule or } \\
\text { nodule in children and young adults }\end{array}$ & $\begin{array}{l}\text { - Most common non-melanoma skin cancer - Pearly } \\
\text { skin-colored papule with telangiectasias on sun- } \\
\text { exposed areas in older individuals }\end{array}$ \\
\hline $\begin{array}{l}\text { Histopathologic } \\
\text { Features }\end{array}$ & $\begin{array}{l}\text { - Islands of basaloid cells that do not interact with } \\
\text { the epidermis - Papillary mesenchymal bodies - } \\
\text { Horn cysts - Fibroblastic stroma - No high-grade } \\
\text { atypia - Few to no mitoses }\end{array}$ & $\begin{array}{l}\text { - Basaloid islands that may connect with the epidermis } \\
\text { - Clefting between tumor and stroma - Peripheral } \\
\text { palisading of basaloid cells - Central cell necrosis - } \\
\text { Myxoid stroma - Mitotic figures }\end{array}$ \\
\hline $\begin{array}{l}\text { Immunohistochemical } \\
\text { Features }\end{array}$ & $\begin{array}{l}\text { Bcl-2: peripheral epithelial expression CD10: stains } \\
\text { stromal cells, especially around the tumor cells } \\
\text { CD34: stains fibroblastic stroma around basaloid } \\
\text { cells }\end{array}$ & $\begin{array}{l}\text { Bcl-2: diffuse expression CD10: stains stromal and } \\
\text { tumor cells CD34: no expression }\end{array}$ \\
\hline
\end{tabular}

TABLE 1: Clinical, histopathologic, and immunohistochemical features of trichoepithelioma and basal cell carcinoma

Trichoepitheliomas are rare, benign neoplasms with three histologic variants: desmoplastic, multiple, and solitary [1-4]. These tumors are thought to originate from follicular germinative cells and result from epithelial-mesenchymal origin cell proliferation $[2,5]$. Trichoepitheliomas can develop in any ethnicity or gender [1]. Males and females are equally affected, although some believe that women have a greater predilection for trichoepithelioma in inherited conditions, since men have lower levels of penetrance and expressivity [1-2]. By contrast, BCCs are the most common non-melanoma skin cancer that can originate from the epidermis or outer root sheath of a hair follicle; it has several histologic subtypes and is most 
Trichoepitheliomas usually present as a skin-colored papule or nodule on the central face of children and young adults $[1-4,8]$. They may also develop in other less common areas such as the neck, scalp, and trunk $[1,4]$. In addition, telangiectasia and central depression may be detected within these lesions $[1,4,8]$. BCC has a similar clinical appearance and is typically found on the head, neck, and other chronically sun-exposed areas in older individuals [6]. BCCs can present as large lesions, unlike trichoepitheliomas that grow slowly over time and typically range from $2 \mathrm{~mm}$ to $8 \mathrm{~mm}$ in size [2]. Our patient's lesion represents an unusual presentation of trichoepithelioma since this neoplasm rarely exceeds $1 \mathrm{~cm}$ in size [4,8].

The diagnosis of trichoepithelioma is classically based upon histologic examination. However, accurate diagnosis is complicated by the many histologic similarities between trichoepithelioma and BCC. Trichoepitheliomas and BCCs both present with nests of basaloid cells with follicular differentiation. Trichoepitheliomas are characterized by islands of basaloid cells that do not interact with the epidermis, papillary mesenchymal bodies, horn cysts, fibroblastic stroma, no high-grade atypia, few or no mitoses, monomorphic nuclei, abortive hair papillae, and occasional calcium deposits [1-4,8-11]. BCCs display basaloid islands that may connect with the epidermis, clefts between the tumor and stroma (retraction artifact), peripheral palisading of basaloid cells, cell necrosis, epidermal ulceration, myxoid stroma, and mitotic figures $[8,10-11]$.

Immunohistochemistry is important in differentiating trichoepitheliomas from BCCs. Clinicians typically use Bcl-2, CD10, CD34, and CK20 immunohistochemical stains to aid in diagnosis. Bcl-2 is an anti-apoptotic protein that is diffusely expressed in BCCs, and only stains peripheral epithelial cells and papillary mesenchymal bodies in trichoepitheliomas [11-12]. In trichoepitheliomas, CD10 only stains stromal cells, particularly those surrounding tumor cells; conversely, CD10 stains both the stromal and tumor cells in BCCs and is classically positive along the periphery of the tumor $[5,13]$. Positive CD34 staining of the fibroblastic stroma surrounding nests of basaloid cells is present in trichoepithelioma and absent in BCC $[2,11]$. CK20 highlights Merkel cells, which are typically present in trichoepitheliomas and rarely found in BCCs $[5,12,14-15]$. However, several studies question the efficacy of CK20 in differentiating trichoepithelioma and BCC, since the quantity of Merkel cells varies between their many histologic subtypes of trichoepitheliomas [12,14-15]. In addition, since this marker highlights only scattered, single cells, it may not be reliable, especially when evaluating a small amount of tissue from a superficial shave biopsy [15].

Several studies have investigated the patterns of other immunohistochemical stains such as cytokeratin 19 (CK19), debrin, nestin, laminin-5, and PHLDA1. CK19 is expressed in germinative basaloid cells and can positively stain both BCCs and trichoepitheliomas [10]. However, one study evaluated patterns of CK19 staining and found diffuse, focal, and negative staining in $60 \%, 28 \%$, and $12 \%$ of BCC cases, respectively [10]. They also showed diffuse, focal, and negative staining in $12 \%, 29 \%$, and $59 \%$ of trichoepithelioma cases, respectively [10]. Therefore, CK19 will most likely diffusely stain BCCs, and remain negative in trichoepitheliomas. Debrin is an F-actin binding protein that appears to be highly and homogenously positive in BCCs and weakly present in a non-homogenous distribution within trichoepitheliomas [5]. Nestin is expressed in mesenchymal cells in hair follicles, and variable expression of nestin in trichoepitheliomas and BCCs is reported in the literature $[11,16]$. Stromal cells are usually positive in trichoepitheliomas and negative in BCCs [16]. However, certain histologic subtypes of BCC (nodular, superficial, infiltrative) show variable, weak nestin expression in their stromal cells [15]. Laminin-5 (laminin-5ץ2 chain) was studied and shown to be positive in $96.2 \%$ of BCCs and in only $12 \%$ of trichoepitheliomas $[11,17]$.

Finally, PHLDA1 (also known as TDAG51) is the most recent immunohistochemical stain that has been investigated for its role in differentiating trichoepithelioma and BCC. PHLDA1 is a proline- and glutaminerich protein involved in apoptosis regulation and is expressed in melanocytes, the basal layer of the follicular bulge, and the lowermost portions of the inner root sheath and catagen follicles [12,14]. PHLDA1 is diffusely positive in trichoepithelioma and negative in BCC (although it may be positive near superficial ulcerations) [14-15]. Thus, some suggest PHLDA1 should replace CK20 since it can more easily and consistently differentiate trichoepithelioma and BCC, even in small biopsy specimens [14-15].

Since trichoepithelioma and BCC possess many similar features, it is important to realize that a superficial shave biopsy may provide inadequate tissue sampling for definitive diagnosis. Therefore, an excisional biopsy may be recommended in order to obtain more lesional tissue and to allow for a more accurate diagnosis.

Some cases have been reported in the literature describing the concomitant presence of a trichoepithelioma and a BCC, as seen in our patient $[9,11,18-20]$. Most of these cases presented patients with both trichoepithelioma and BCC in the setting of genetic syndromes such as Brooke-Spiegler syndrome, familial cylindromatosis, or multiple familial trichoepithelioma [9,18-19]. These conditions are all due to germline mutations of the cylindromatosis (CYLD) gene on chromosome 16q12-q13, which lead to uncontrolled activity of NF-KB, and ultimately, cell proliferation [1,8-9]. 
usually arises in patients with multiple trichoepitheliomas [11,20]. Although trichoepitheliomas are generally thought to be benign neoplasms, they can rarely undergo malignant transformation, which is important for clinicians to consider when making diagnostic and therapeutic decisions [11,19-20]. In addition, the coexistence of trichoepithelioma and BCC may be the result of two neoplasms (a collision tumor) independently developing in the same location $[11,20]$. Our patient illustrates a unique presentation of a BCC arising within a trichoepithelioma.

The treatment of trichoepithelioma includes laser, cryotherapy, dermal abrasion, electrodessication and curettage, radiation, and surgery [1-3]. Surgical removal can safely remove the lesion and is a particularly important modality when concomitant neoplasms or malignant transformation is suspected [2].

\section{Conclusions}

Trichoepithelioma is a tumor that seldom grows beyond $1 \mathrm{~cm}$ in size and rarely undergoes malignant transformation. However, clinical and histological diagnosis of trichoepithelioma is sometimes complicated by its many similarities to BCC. As such, immunohistochemical analysis and adequate tissue sampling are essential in suspicious lesions. Our patient presented with a BCC arising within a large, atypical trichoepithelioma. Therefore, it is important for clinicians to remember that trichoepitheliomas may coexist with malignant neoplasms and that a superficial shave biopsy may not be sufficient for accurately diagnosing suspicious lesions.

\section{Additional Information \\ Disclosures}

Human subjects: Consent was obtained by all participants in this study. N/A issued approval N/A. N/A. Conflicts of interest: In compliance with the ICMJE uniform disclosure form, all authors declare the following: Payment/services info: All authors have declared that no financial support was received from any organization for the submitted work. Financial relationships: All authors have declared that they have no financial relationships at present or within the previous three years with any organizations that might have an interest in the submitted work. Other relationships: All authors have declared that there are no other relationships or activities that could appear to have influenced the submitted work.

\section{References}

1. Johnson H, Robles M, Kamino H, Walters RF, Lee A, Sanchez M: Trichoepithelioma. Dermatol Online J. 2008, 14:5.

2. Mohammadi AA, Jafari SMS: Trichoepithelioma: a rare but crucial dermatologic issue . World J Plast Surg. 2014, 3:142-145.

3. Kataria U, Agarwal D, Chhillar D: Familial facial disfigurement in multiple familial trichoepithelioma . J Clin Diagn Res. 2013, 7:3008-3009. 10.7860/JCDR/2013/6218.3830

4. Lazaridou E, Fotiadou C, Patsatsi A, Fotiadu A, Kyrmanidou E, Kemanetzi C, Ionnides D: Solitary trichoepithelioma in an 8-year-old child: clinical, dermoscopic and histologic findings. Dermatol Pract Concept. 2014, 4:55-58. 10.5826/dpc.0402a11

5. Mizutani Y, Iwamoto I, Kanoh H, Seishima M, Nagata K: Expression of debrin, an actin binding protein, in basal cell carcinoma, trichoblastoma and trichoepithelioma. Histol Histopathol. 2014, 29:757-766. 10.14670/HH-29.757

6. Andrade P, Vieira R, Reis JP, Brites MM, Mariano A: Epidemiology of basal cell carcinomas and squamous cell carcinomas in a Department of Dermatology: a 5 year review. An Bras Dermatol. 2012, 87:212-219. 10.1590/s0365-05962012000200004

7. Souza CFD, Thomé EP, Menegotto PF, Schmitt JV, Shibue JRT, Tarlé RG: Topography of basal cell carcinoma and their correlations with gender, age and histologic pattern: a retrospective study of 1042 lesions. An Bras Dermatol. 2011, 86:272-277. 10.1590/s0365-05962011000200010

8. Arits AH, Parren LJ, van Marion AM, Sommer A, Frank J, Kelleners-Smeets NW: Basal cell carcinoma and trichoepithelioma: a possible matter of confusion. Int J Dermatol. 2008, 47:13-17. 10.1111/j.13654632.2008.03951.x

9. Hester CC, Moscato EE, Kazakov DV, Vanecek T, Moretto JC, Seiff SR: A new cylindromatosis (CYLD) gene mutation in a case of Brooke-Spiegler Syndrome masquerading as basal cell carcinoma of the eyelids. Ophthal Plast Reconstr Surg. 2013, 29:10-11. 10.1097/IOP.0b013e3182565c41

10. Bedir R, Sehitoglu I, Yurdakul C, Saygin I, Ustuner P, Dilek N: The importance of cytokeratin 19 expression in the differentiation of basal cell carcinoma and trichoepithelioma. J Clin Diagn Res. 2015, 9:1-4. 10.7860/JCDR/2015/10915.5414

11. Wallace ML, Smoller BR: Trichoepithelioma with an adjacent basal cell carcinoma, transformation or collision?. J Am Acad Dermatol. 1997, 37:343-345.

12. Yeh I, McCalmont TH, LeBoit PE: Differential expression of PHLDA1 (TDAG51) in basal cell carcinoma and trichoepithelioma. Br J Dermatol. 2012;167, 1106:1110. 10.1111/j.1365-2133.2012.11165.x

13. Sari Aslani F, Akbarzadeh-Jahromi M, Jowkar F: Value of CD10 expression in differentiating cutaneous basal from squamous cell carcinomas and basal cell carcinoma from trichoepithelioma. Iran J Med Sci. 2013, 38:100-106.

14. Battistella M, Peltre B, Cribier B: PHLDA1, a follicular stem cell marker, differentiates clear-cell/granularcell trichoblastoma and clear-cell/granular cell basal cell carcinoma: a case-control study, with first description of granular-cell trichoblastoma. Am J Dermatopathol. 2014, 36:643-650. 


\section{Cureus}

10.1097/DAD.0b013e31828a31ae

15. Sellheyer K, Nelson P: Follicular stem cell marker PHLDA1 (TDAG51) is supreior to cytokeratin-20 in differentiating between trichoepithelioma and basal cell carcinoma in small biopsy specimens. J Cutan Pathol. 2011, 38:542-550. 10.1111/j.1600-0560.2011.01693.x

16. Misago N, Mori T, Narisawa Y: Nestin expression in stromal cells of trichoblastoma and basal cell carcinoma. J Eur Acad Dermatol Venereol. 2010, 24:1354-1358. 10.1111/j.1468-3083.2010.03641.x

17. Hamasaki H, Koga K, Aoki M, et al.: Immunohistochemical analysis of laminin 5- $\gamma 2$ chain expression for differentiation of basal cell carcinoma from trichoblastoma. Histopathology. 2011, 59:159-161. 10.1111/j.1365-2559.2011.03871.x

18. Melly L, Lawton G, Rajan N: Basal cell carcinoma arising in association with trichoepithelioma in a case of Brooke-Spiegler syndrome with a novel genetic mutation in CYLD. J Cutan Pathol. 2012, 39:977-978. 10.1111/j.1600-0560.2012.01952.x

19. Johnson SC, Bennett RG: Occurrence of basal cell carcinoma among multiple trichoepitheliomas . J Am Acad Dermatol. 1993, 28:322-326. 10.1016/0190-9622(93)70046-v

20. Martinez CA, Priolii DG, Piovesan H, Waisberg J: Nonsolitary giant perianal trichoepithelioma with malignant transformation into basal cell carcinoma: report of a case and review of the literature. Dis Colon Rectum. 2004, 47:773-777. 10.1007/s10350-003-0104-8 